\title{
INSIGNIFICANCE OF ADMINISTRATIVE MISCONDUCT REGARDING THE CONFLICT OF INTEREST: ACCEPTABILITY AND CRITERIA
}

Khamkhodera O. P.

\section{INTRODUCTION}

Bringing to administrative responsibility for violation of requirements for the prevention and settlement of conflict of interest is characterized is characterized by the differences in law enforcement practice and uncertainty about a number of applied aspects of proper qualification of offenses: the complexity of situations related to the activities of collegial public authorities or the existence of an advisory decision of the collegial body preceding the issuance of the administrative act; the importance of subjective awareness / identification of private interest, along with the urgency of its clear articulation by the law enforcement agency; distinguishing between real and potential conflicts of interest; the probable significance of improper performance of official duties as a means of proving the negligence of the conflict of interest (and hence the absence of the latter); the difficulty of identifying an imaginary and supposed conflict of interest, identifying and applying legal facts that prevent tort proceedings; non-harmonization of general and special anti-corruption regulations (in particular, regarding the conflict of interests of members of collegial bodies and the conflict of interests of deputies of local councils); the problem of defining the range of officials of legal entities of public law, other aspects of proper identification of functionaries and quasi- functionaries; proof of the subjective side of the relevant torts. One of the polemical aspects of the considered sector of administrative-jurisdictional law enforcement is, in our opinion, the issue of admissibility / inadmissibility of the application of Art. 22 of the Code of Ukraine on Administrative Offenses (hereinafter the Code on Administrative Offenses) in relation to administrative offenses of conflict of interest (and in general - in relation to all sectoral offenses related to corruption). St. 22 of the Code on Administrative Offenses stipulates that «in case of insignificance of the committed administrative offense, the body (official) authorized to decide the case may exempt the infringer from administrative liability and limit itself to oral rebuke» ${ }^{1}$.. As the legislation

${ }^{1}$ Кодекс України про адміністративні правопорушення: Закон України від 07.12.1984 № 8073-X. URL: https://zakon.rada.gov.ua/laws/show/80731-10 (дата звернення: 05.07.2020). 
does not contain a list of specific torts in respect of which the said article is envisaged, as well as there are no indications of signs that would allow to reliably judge the insignificance of guilt, there is a particularly controversial and urgent problem of admissibility in some cases of exemption from liability for administrative offenses related to corruption (including those related to conflicts of interest), due to the insignificance of the committed. The views of scholars and practitioners on the proper way to solve this dilemma differ significantly, understanding the prospects of its positive legal regulation, as well as acceptable criteria and applied principles, have not received sufficient doctrinal elaboration, which collectively determines the relevance of the chosen direction of cognitive search.

\section{The issue of admissibility of exemption from administrative liability due to the insignificance for offenses related to conflicts of interest}

It can be distinguished the three key approaches to resolving the controversy over the acceptability of the application of Art. 22 of the Code on Administrative Offenses regarding administrative misconducts related to corruption, in general and in relation to Art. 172-7 of the Code on Administrative Offenses («Violation of requirements for the prevention and settlement of conflicts of interest»), in particular:

1) Categorically negative positions, within which experts give an unequivocally negative answer to the question discussed (in the existing positive legal context and mainly for applied purposes). Thus, according to G. Boreyko, violations related to corruption can not be insignificant, because «now the state especially increases the responsibility for committing corruption offenses, society categorically does not accept the corruption» ${ }^{2}$. The Court of Appeal of Kyiv region in the Resolution of December 19, 2017 (case № 359/7200/17) takes a similar position, recognizing the arguments that «the commission of administrative offenses related to corruption committed by officials indicates ignoring the anti-corruption policy of the state, undermines the country's authority, damages the democratic principles of governance, the functioning of the state apparatus, rather than being held accountable for the offense, discredits the state and destroys the mechanism of anti-corruption resistance defined by the Law of Ukraine «On Prevention of Corruption» ${ }^{3}$.

\footnotetext{
${ }^{2}$ Бурбан Л. У прокуратурі Львівщини скаржаться на недосконалість антикорупційного законодавства. Leopolis.news від 30 Січня 2017. URL: http://leopolis.news/u-prokuraturilvivskoyi-oblasti-zhaliyutsya-na-nedoskonalist-antykoruptsijnogo-zakonodavstva/ (дата звернення: 05.07.2020).

3 Постанова Апеляційного суду Київської області від 19 грудня 2017 р., справа № 359/7200/17. UR L: http://www.reyestr.court.gov.ua/Review/71277204 (дата звернення: 05.07.2020).
} 
In the Resolution of January 24, 2017 (case № 636/144/17), the Chuhuyivskyy Court of the Kharkiv Region noted: «The application in this case of Art. 22 of the Code on Administrative Offenses is impossible, as all offenses related to the fight against corruption have an increased public danger and cannot be considered insignificant» ${ }^{4}$. It should be noted that the very characterization of the particular misconducts as having «increased public danger» is questionable, because: a) public danger is a sign of crime, and in general could not be inherent in administrative torts; b) «increased» public danger is characteristic only of certain categories of crimes and, in particular, a similar (not identical) epithet is used in paragraphs. 1 item 3 of section 4 of the Principles of State Anti-Corruption Policy in Ukraine (Anti-Corruption Strategy) for 2014-2017 in justifying the establishment of a specially authorized body for detection and investigation of corruption crimes, the competence of which is based on «specialization of the body in corruption crimes committed by officials of higher level, judges, prosecutors, other persons, provided that the corruption crime constitutes a high public danger» ${ }^{5}$.

The fundamental denial of the probability of application of Art. 22 of the Code on Administrative Offenses to the investigated category of misconducts is observed in the Analysis of judicial practice of court proceedings on administrative offenses related to corruption in 2016, conducted by the Court of Appeal of Donetsk region, which provides the following unifying position: «Prevention of offenses related to corruption, in the generally defined policy of the state has a preventive and prejudicial nature in such an extremely negative phenomenon for society as corruption. In view of the above-mentioned, the actions for which liability is provided by Chapter 13-A of the Code on Administrative Offenses, cannot be considered insignificant in the sense of Art. 22 of the Code on Administrative Offenses» ${ }^{6}$. It appears that the cited and other relevant approaches need to be taken quite critically, leaving place for an alternative, because:

Firstly, positive law does not impose restrictions on the application of Art. 22 to certain types of administrative misconducts, including those related to corruption. Only when the current legislation clearly prohibits

${ }^{4}$ Постанова Чугуївського міського суду Харківської області від 24 січня 2017 р., справа № 636/144/17. URL: http://www.reyestr.court.gov.ua/Review/64358464 (дата звернення: 05.07.2020).

5 Про засади державної антикорупційної політики в Україні (Антикорупційна стратегія) на 2014-2017 роки: Закон України від 14 жовтня 2014 року № 1699-VII. URL: https://zakon.rada.gov.ua/laws/show/1699-18\#Text (дата звернення: 05.07.2020).

${ }^{6}$ Аналіз судової практики розгляду судами справ про адміністративні правопорушення, пов'язані з корупцією (ст.ст. 172-2-172-9 КУпАП) за 2016 р. Апеляційний суд Донецької області. 2017. URL: https://sl.dn.court.gov.ua/sud0544/pres-centr/general/364605/ (дата звернення: 05.07.2020). 
the implementation of facilitative tort-legal mechanisms for certain types of violators / violations, such a ban will be valid. In particular, it can observed an appropriate approach when excluding persons who have committed corruption crimes from the scope of application of such institutions of criminal law as: exemption from criminal liability in connection with effective repentance; exemption from criminal liability in connection with the reconciliation of the perpetrator with the victim; exemption from criminal liability in connection with the transfer of a person on bail; exemption from criminal liability in connection with a change of circumstances; imposing a milder punishment than provided by law; exemption from punishment and its serving; exemption from serving a probation sentence; exemption from serving a sentence with probation of pregnant women and women with children under the age of seven (Part 1 of Article 45, Part 1 of Article 46, Part 1 of Article 47, Part 1 of Article 48, Part 1 Article 69, Part 4, Article 74, Part 1, Article 75, Part 1, Article 79 of the Criminal Code of Ukraine) ${ }^{7}$; when establishing increased requirements for early parole of persons who have committed corruption offenses (Part 3 of Article 81 of the Criminal Code of Ukraine). Instead, the absence in the formalized sources of administrative law of the requirement about non-appliance of Art. 22 allows to state the arbitrariness of premature dogmatic-directive restriction by the jurisdictional body of its functional legal obligations. In such cases, the subject of authority actually refuses to legally assess the act as «insignificant» instead of assessing and concluding that it is insignificant or non-insignificant. Instead, in a number of law enforcement decisions there is a more balanced wording: «The court has not established the grounds and evidence that justify the application of the provisions of Art. 22 of the Code on Administrative Offenses and exemption of a person from administrative liability in connection with the insignificance of the committed administrative offenses ${ }^{8}$. It states that the lead entity has deviated from unequivocally biased judgments, admitted (at the level of fundamental probability) the insignificance of misconducts related to the conflict of interest, but did not find it in specific jurisdictional situations.

Secondly, based on the grounds of the basic civilizational principle of the rule of law and one of its ideological and applied expressions (which is

\footnotetext{
${ }^{7}$ Кримінальний кодекс України: Закон України від 05.04.2001 p. № 2341-III. URL: https://zakon.rada.gov.ua/laws/show/2341-14\#Text (дата звернення: 05.07.2020).

${ }^{8}$ Постанова Кролевецького районного суду Сумської області від 28 січня 2020 р., справа № 579/2252/19. URL: http://www.reyestr.court.gov.ua/Review/87219703 (дата звернення: 05.07.2020). Постанова Роменського міськрайонного суду Сумської області від 27 травня 2020 р., справа № 585/692/20. URL: http://www.reyestr.court.gov.ua/Review/89500524 (дата звернення: 05.07.2020).
} 
reflected in some domestic laws: Part 4 of Article 3 of the Customs Code of Ukraine, paragraph 4.1.4, paragraph 4.1 of Article 4 of the Tax Code of Ukraine): uncertainty of legal requirements is interpreted in favour of the person. That is, even if there is a legal prescription that, due to its ambiguity or terminological or evaluative polemics, allows for a different interpretation of good behaviour, preference should be given to a version of its interpretation that is consistent with the rights and interests of the individual. Instead, a categorically negative approach proposes (and embodies) an even more unacceptable legal construction: in the absence of ambiguity or grounds for misinterpretation (legislation does not impose any restrictions on the application of Article 22 of the Code on Administrative Offenses), to interpret the existing positive right to harm an individual (excluding the possibility of closing an administrative case against person for insignificance). The departure from the ideals of «the rule of law» is obvious to us. And this digression cannot be justified by applied problems of public governance (destructive influence of corruption), relevance of anti-corruption policy or subjective understanding of the importance of one or another sphere of public relations (direction of administration, type of public activity, type of public service, etc.). A striking example of the hyperbolized perception of the role of «own» sector of public affairs, which distorts the vision of proper jurisdictional proceedings, we find in the work of O. Senyuk: «Courts closed two proceedings due to insignificance. In considering these cases, the courts did not fully take into account the nature of the offenses related to corruption and the fact that the illegal actions of a person violate the established procedure for the exercise of powers by officials and functionaries of military units» ${ }^{9}$. The military (like any other) sphere does not determine the unconditionally increased harmfulness of all non-specialized misconducts related to it (and, accordingly, the inadmissibility of the application of Article 22).

Thirdly, the determination of the state's anti-corruption policy and the urgency of combating corruption (as we can summarize most of the arguments in favour of the impossibility of recognizing the misconducts in question insignificant) are political phenomena, and until they are reflected in tortious legal regulations, they should not be a guideline for jurisdictional law enforcement. For the relevant reasons, it is permissible only to talk about the urgency of updating existing legislation, but no

\footnotetext{
${ }^{9}$ Сенюк О. Протидія корупційним правопорушенням у Збройних Силах України та інших військових формуваннях. Протидія корупиійним та іншим правопорушенням у військових формуваннях України: матеріали круглого столу (19 вересня 2017 року). Київ: Національна академія прокуратури України, 2017. С. 83.
} 
more. Based on the above, we support the potential and promising nature of the position of A. Ivanov: "for minor corruption offenses it would be sufficient to bring the perpetrator to disciplinary responsibility, and when considering cases of more serious administrative corruption offenses courts should be prohibited from applying to corrupt officials Art. 22 of the Code on Administrative Offences and close the proceedings for insignificance» ${ }^{10}$. It seems appropriate to further emphasize: a) we share precisely the recommendatory-non-categorical way of formulating an opinion, but not its content; b) the designation «corrupt person» does not correspond to the nature of administrative misconducts related to corruption ${ }^{11}$. In general, the judgment cited above traces a second approach to the question of the admissibility of the insignificance of corruption-related misconducts.

2. Moderately negative visions, within which the possibility of applying Art. 22 of the Code on Administrative Offenses to administrative torts related to corruption (including conflicts of interest), but this is regarded as due to positive legal requirements of coercion, which in the future should be eliminated by appropriate legislation. According to researchers, giving the court the power to exempt a person from administrative liability due to the insignificance of the offense makes it impossible to effectively implement the NAPC's preventive function. After all, the current state of the level of corruption in Ukraine suggests that such a phenomenon requires a tough fight against it, that is, even a «minor» violation of anti-corruption legislation should entail responsibility ${ }^{12}$. At the same time, the negative consequence of recognizing an administrative offense related to corruption is not only that the perpetrator is not prosecuted, but also that the anti-corruption mechanism defined by law is destroyed: the person who committed an offense related to corruption, which is considered insignificant, is not subject to mandatory dismissal; information about it is not entered into USRPCO; elimination of the consequences of the offense (compensation for damages, damage, seizure of illegally obtained property) requires additional recourse to the

\footnotetext{
${ }^{10}$ Іванов А. Розгляд у суді справ про адміністративні корупційні правопорушення. Micцеве самоврядування. 2015. № 5. URL: https://i.factor.ua/ukr/journals/ms/2015/april/issue-4/ article-7116.html (дата звернення: 05.07.2020).

11 Хамходера О.П. Малозначність адміністративних проступків, що пов'язані 3 корупцією. Правові та інституційні механізми забезпечення розвитку Украӥни в умовах європейської інтеграції: матеріали Міжнародної науково-практичної конференції (м. Одеса, 18 травня 2018 р.). У 2-х т. Т. 2 / від. ред. Г.О. Ульянова. Одеса: Гельветика, 2018. С. 50-51.

12 Хавронюк М., Химчук А. Моніторинговий звіт щодо ефективності реалізації Національним агентством з питань запобігання корупції у ліпні-грудні 2018 року повноважень щодо складання протоколів про адміністративні правопорушення, пов'язані з корупцією (станом на 1 січня 2019 року). Київ: ЦППР, 2019. С. 16.
} 
court in civil proceedings, etc ${ }^{13}$. There is a prevailing position among anticorruption experts: given the existing case law, which clearly reduces the effectiveness of anti-corruption, does not prevent the commission of new offenses by the offender and others, and characterizes the legal provision on exemption from administrative liability for insignificance as corruptioncausing factor, understandable and deserving of support, is a doctrinal proposal to exclude in the legislative order the possibility of applying Art. 22 of the Code on Administrative Offenses to the offenses provided for in Chapter 13-A of the Code on Administrative Offenses «Administrative Offenses Related to Corruption» ${ }^{14}$. While acknowledging much of the criticism of the current practice of exemption from liability for corruptionrelated misconduct due to the insignificance of the offense, we still do not support the prospect of thematic narrowing of the scope of Art. 22 of the Code on Administrative Offenses. This approach is determined by a set of judgments, which can be disclosed through a set of the following theses:

- if the criminal law does not restrict the application of the instrument of «insignificance» to corruption offenses (Part 2 of Article 11 of the Criminal Code of Ukraine; regarding the justification of this, we admit, experts are not unanimous), then for administrative misconducts related to corruption, such a tool is more suitable;

- there are real cases when the tort does not harm the protected public relations and justice itself requires the exempt from liability of a bona fide individual. In this context, it is significant the position of the lawyers, who

\footnotetext{
13 Дудоров О.О. Узагальнення судової практики у справах про адміністративні правопорушення, пов'язані з корупцією. Київ. 2019. C. 40. URL: https://fileview.fwdedn.com/ ?url=https $\% 3 \mathrm{~A} \% 2 \mathrm{~F} \% 2 \mathrm{Fmail} . u k r . n e t \% 2 \mathrm{Fapi} \% 2 \mathrm{Fpublic} \% 2 \mathrm{Ffile}$ view $\% 2 \mathrm{Flist} \% 3 \mathrm{Ftoken} \% 3 \mathrm{DWr} 3$ PDezpM3JWw6jJAqHFFbiqP2FbV6nFh6ecAPp5ccEqnqc7ENtQF_JhCnsrCHGAlrAniwhVBdd Lw2aVZN49QNyVyeZ7gqftrrVgIw\%253A8dsXG9b0cuUfgWwR\%26r\%3D1579727886832\&de fault_mode=view\&lang=uk\#start=1 (дата звернення: 05.07.2020).

14 Дудоров О.О. Узагальнення судової практики у справах про адміністративні правопорушення, пов'язані з корупцією. Київ. 2019. С. 40. URL: https://fileview.fwdcdn. com/?url=https $\% 3 \mathrm{~A} \% 2 \mathrm{~F} \% 2 \mathrm{Fmail} . u k r . n e t \% 2 \mathrm{Fapi} \% 2 \mathrm{Fpublic} \% 2 \mathrm{Ffile}$ view $\% 2$ Flist $\% 3$ Ftoken $\% 3 \mathrm{D}$ Wr3PDezpM3JWw6jJAqHFFbiqP2FbV6nFh6ecAPp5ccEqnqc7ENtQF_JhCnsrCHGAlrAniwhV BddLw2aVZN49QNyVyeZ7gqftrrVgIw\%253A8dsXG9b0cuUfgWwR\%26r\%3D1579727886832 \&default_mode=view\&lang=uk\#start=1 (дата звернення: 05.07.2020). Гладун О.З. Малозначність кримінальних і адміністративних правопорушень. Боротьба з організованою злочинністю і корупцією (теорія і практика). 2012. № 2. С. 103-112. Діденко І.В. Адміністративна відповідальність за порушення вимог щодо запобігання та врегулювання конфлікту інтересів: дис. ... канд. юрид. наук. Київ, 2018. С. 106 і 184. Дудоров О.О., Мовчан Р.О. Національне агентство 3 питань запобігання корупції на варті «попереднього» рубежу протидії корупції: основні проблеми та способи їх вирішення. Вісник ЛДУВС ім. Е.О. Дідоренка. 2018. Вип. 3(83). С. 69. Соболь О. Проблемні питання апеляційного оскарження постанов у справах про адміністративні правопорушення, пов'язані з корупцією. Вісник прокуратури. 2017. № 11. С. 37.
} 
adhere mainly to a moderately negative approach, the acceptability and expediency of the application of Art. 22 to separate thematic torts ${ }^{15}$;

- manifestations of ungrounded application of «insignificance» to corruption-related administrative misconducts, disharmony of jurisdictional practice, etc. constitute a praxeological problem that must be overcome by the help of applied means (generalization of practice, development of recommendations, application of appeal mechanisms, etc.). In addition, the renewal of substantive or procedural law may be motivated by their own qualitative trends / incentives, but not by the urgency of leveling the defects of state-building or nomination processes. Organizational and institutional problems (including potential bad faith of the leading entity) are not solved by truncating legal opportunities or deforming legal regimes;

- exceptions to the scope of any legal institution or instrument should be determined primarily by its nature and system, and not by the specifics of the social sector. Otherwise, they become a step towards more and more exceptions. There are many other important social relations in which offenses (for various reasons and at first glance) can hardly be called «insignificant»: health, ecology, road safety, catering, suffrage realization, military discipline, protection from violence, etc. As experts of the Main Scientific and Expert Department of the Verkhovna Rada of Ukraine rightly noted, the one-time introduction of special exceptions to Art. 22 of the Code on Administrative Offenses «may create a negative precedent of unjustified expansion of the list of offenses to the subjects of which the relevant types of exemption from administrative liability cannot be applied ${ }^{16}$;

- exemption from administrative liability for corruption-related misconduct due to the insignificance of the offense does not destroy the public law mechanism for combating corruption and does not encourage new torts. On the contrary, if as a result of proceedings on a thematic tort, Art. 22 of the Code on Administrative Offenses is applied: a) it affirms the principle of proportionality and strengthens the «faith» of individuals in the justice of the law (because no less negative would be a situation where

15 Див.: Дудоров О.О. Узагальнення судової практики у справах про адміністративні правопорушення, пов'язані 3 корупцією. Київ. 2019. С. 44. URL: https://fileview.fwdcdn.com/ ?url=https $\% 3 \mathrm{~A} \% 2 \mathrm{~F} \% 2 \mathrm{Fmail}$. ukr.net $\% 2 \mathrm{Fapi} \% 2 \mathrm{Fpublic} \% 2 \mathrm{Ffile}$ view $\% 2 \mathrm{Flist} \% 3 \mathrm{Ftoken} \% 3 \mathrm{DWr} 3$ PDezpM3JWw6jJAqHFFbiqP2FbV6nFh6ecAPp5ccEqnqc7ENtQF_JhCnsrCHGAlrAniwhVBdd Lw2aVZN49QNyVyeZ7gqftrrVgIw\%253A8dsXG9b0cuUfgWwR\%26r\%3D1579727886832\&de fault_mode=view\&lang=uk\#start=1 (дата звернення: 05.07.2020).

${ }^{16}$ Висновок Головного науково-експертного управління від 11.02.2020 р. на проект Закону України «Про внесення змін до деяких законодавчих актів України щодо посилення відповідальності за окремі правопорушення у сфері безпеки дорожнього руху». C. 2. URL: http://w1.c1.rada.gov.ua/pls/zweb2/webproc4_1?pf3511=67814 (дата звернення: 05.07.2020). 
positivism and limited scope of «insignificance» would force sanctions for formal / insignificant deviations; for example, for delaying the filing of the declaration for 5 minutes; this will also cause significant and obvious damage to law and order); b) the person (and others) is aware that even minor violations are not left without a balanced law enforcement assessment; c) for most functionaries, the «insignificance» of an administrative tort would mean the exemption from specific, rather than any, liability. As explained by the NAPC, «the basis for initiating disciplinary proceedings against a state servant is the receipt by a public authority of one of the following court decisions:... 3) a decision to close the case on non-rehabilitative grounds, in particular, due to the expiration of the administrative penalty; provided for in Article 38 of the Code of Ukraine on Administrative Offenses, as well as in the case of exemption from administrative liability in case of insignificance of the offense on the basis of Article 22 of the Code of Ukraine on Administrative Offenses) $\gg{ }^{17}$. That is, the exemption from administrative liability determines a very real prospect of bringing a person to disciplinary responsibility for the act. It will also be recalled that the Unified State Register of Persons Who Have Committed Corruption or CorruptionRelated Offenses includes information on «individuals who have been prosecuted for criminal, administrative, disciplinary and civil liability for committing corruption or corruption-related offenses $»{ }^{18}$. Thus, the claims of researchers that the application of Art. 22 of the Code on Administrative Offenses to the analyzed torts clearly reduces the effectiveness of anticorruption, does not prevent the commission of new offenses and acts as a corruption-causing factor (undermining the anti-corruption mechanism).

3. Considering all the above, we follow the third - moderately positive approach. The closure of administrative misconduct cases involving corruption offenses (including conflicts of interest) appears to be a perfectly acceptable (and in some cases even the only possible and legitimate) way to complete tort proceedings.

The difference between moderately negative and moderately positive visions of the issues under consideration is due to the actualization of different legal values, which leads to opposing views on the anti-corruption

\footnotetext{
${ }^{17}$ Щодо порядку дій державних органів після визнання державних службовців судом винними у вчиненні корупційного правопорушення або правопорушення, пов'язаного 3 корупцією: Роз'яснення НАЗК від 03.06.2020 p. № 3. URL: https://nazk.gov.ua/wp-content/ uploads/2020/06/3.pdf (дата звернення: 05.07.2020).

18 Положення про Єдиний державний реєстр осіб, які вчинили корупційні або пов'язані з корупцією правопорушення: затв. Рішенням НАЗК від 09.02.2018 р. № 166. URL: https://zakon.rada.gov.ua/laws/show/z0345-18\#n13 (дата звернення: 05.07.2020).
} 
prospects of administrative «insignificance». At the same time, for the needs of modern law enforcement, they defend a common dominant: the misconducts provided for in Chapter 13-A of the Code on Administrative Offenses may be considered insignificant. The latter, as it appears on the basis of the analysis of jurisdictional practice, gained an applied advantage during 2018-2020. In this period, categorically negative praxeological approaches are much less common (compared to 2015-2017). They can only be seen indirectly, for example, in the wording of the Resolution of the Zavodsky District Court of Dniprodzerzhynsk dated 08.07.2019 (case № 208/2949/19) - «There are no signs of insignificance of the offense, considering the importance of strict compliance with anti-corruption legislation ${ }^{19}$ or in the content of the Resolution of the Kyiv Court of Appeal of 16.12.2019 (case № 365/572/19) - «Recognition of minor administrative offenses related to corruption is contrary to the principles of prevention of corruption ${ }^{20}$. Approved in practice (and recognized by us theoretically) the admissibility of the application of Art. 22 to administrative misconducts on conflict of interest does not exclude the expediency to note the existence of cases of unjustified exemption from liability. This requires an analysis of the criteria for determining the insignificance, their harmony in the composition and properties of the relevant misconducts - as interpretive problems of the implementation of Art. 22 of the Code on Administrative Offenses.

\section{Criteria of insignificance at exemption from administrative responsibility for misconducts connected with the conflict of interests}

In general, in law enforcement practice (outside the specifics of the investigated torts) take into account the following features to determine the insignificance of the misconduct: sincere remorse of the perpetrator; committing an offense by a person for the first time; severe financial condition of the violator; the violation was eliminated at the time of the case; the person has dependents ${ }^{21}$; subjective understanding by the victim of the

\footnotetext{
19 Постанова Заводського районного суду м. Дніпродзержинська Дніпропетровської області від 08.07.2019 р., справа № 208/2949/19. URL: http://www.reyestr.court.gov.ua/ Review/83035058 (дата звернення: 05.07.2020).

${ }^{20}$ Постанові Київського апеляційного суду від 16.12 .2019 р., справа № 365/572/19. URL: http://www.reyestr.court.gov.ua/Review/86394266 (дата звернення: 05.07.2020).

21 Аналіз судової практики розгляду справ про адміністративне правопорушення, розглянутих місцевими судами області та їх перегляд апеляційним судом Івано-Франківської області за I півріччя 2015 року. 2015. C. 23. URL: https://ifa.court.gov.ua/userfiles/file/ifa_sud/ ANALIZ_KYpAP.pdf (дата звернення: 05.07.2020).
} 
insignificance / non-insignificance of the damage caused to him $^{22}$; the cost and number of objects of the offense, as well as the purpose, motive and manner of its commission ${ }^{23}$. Obviously, some of these features cannot be applied to the considered misconducts, because they do not correlate with their nature; in particular, there are no victims in the commission of the latter, and therefore their understanding of the role of the damage is excluded. Analysis of the practice of exemption from liability in cases of administrative misconducts under Art. 172-7 of the Code on Administrative Offenses, allows to compose the following list of characteristics by means of which courts mainly identify / substantiate insignificance of the conflict of interests: sincere remorse of the person; bringing to administrative responsibility for the first time; non-disciplinary action; positive characteristics from the place of work and from the place of residence; availability of dependents; no harm to society, rights or freedoms of individuals; voluntary post-tort cessation of illegal conduct or performance of an unfulfilled duty; data about the person (his social-personal-service-age features); lack of significant harm to the interests of the state; no harm (and no focus on harm) to the interests of society, legal entities and individuals; the absence of serious consequences from the violation or its great social danger; no aggravating circumstances and / or mitigating circumstances; minor degree of guilt; lack of intent (careless form of guilt); misconduct as a result of a good faith mistake; absence of victims of the offense; confession of guilt; lack of subjective illegal attitude; insignificant amount of benefit obtained as a result of the tort; factual ignorance of the content of anti-corruption requirements (in particular, failure to explain or improper explanation to the person); essential compliance of the decision made in the conditions of conflict of interests with the requirements of substantive law; indecision of the lawenforcement will of the violator, etc. The heterogeneity of these features, the difference in the legal nature of many of them, requires a revision of the criteria of «insignificance». Article 22 of the Code on. Administrative Offenses does not define the concept or criteria of insignificance of the offense, which allows in each case the body authorized to decide the case, to conclude that

\footnotetext{
22 Узагальнення застосування судами законодавства у справах про адміністративні правопорушення у сфері інтелектуальної власності (статті 51-2, 164-9 КпАП): Верховний Суд України від 01.01.2006 p. URL: http://zakon3.rada.gov.ua/laws/show/na018700-06/ print1516951598059782 (дата звернення: 05.07.2020). Резнік С.О. Судова практика звільнення особи від адміністративної відповідальності у зв'язку зі малозначністю протиправного діяння. Право і суспільство. 2009. № 3. С. 69-73.

${ }^{23}$ Про судову практику у справах про контрабанду: Постанова Пленуму Верховного Суду України від 03.06.2005 р. № 8. п. 9. URL: http://zakon5.rada.gov.ua/laws/show/v0008700-05 (дата звернення: 05.07.2020).
} 
it is insignificant at its discretion, according to personal perceptions of the list of offenses that may be considered insignificant. also about the signs that indicate the insignificance of an $\operatorname{act}^{24}$. Already, O.O. Dudorov and R.O. Movchan rightly note that most used in the application of Art. 22 of the Code on Administrative Offenses of substantiating circumstances can serve as a basis except for the individualization of administrative responsibility, but not exemption from $i^{25}$. As a guide for finding acceptable criteria for the insignificance of administrative misconducts related to conflicts of interests, it seems justified to turn to the practical and theoretical achievements of criminal law. Normative description of «insignificance» in Part 2 of Art. 11 of the Criminal Code of Ukraine, although more detailed than in administrative tort law, it is about two protective, historically interrelated and doctrinably correlated legal entities (the validity of intersectoral search is indirectly confirmed by the fact that the draft Code on Administrative Offenses provided in 2004 year «updated» interpretation of insignificance ${ }^{26}$, which substantively and terminologically reproduced the criminal law approach).

According to the legal position of the Supreme Court, for criminal offenses the specificity of establishing the insignificance of the act lies in the mandatory set of three conditions: 1) the formal presence in the act of signs of a crime under the Criminal Code of Ukraine, i. e.all those effective signs that in the relevant article (part of the article) of the Special Part of the Criminal Code of Ukraine characterize a certain crime; 2) a minor act does not constitute a public danger that is typical of a particular crime. This is expressed in the fact that it does not cause any harm to a natural or legal person, society or the state, or causes them clearly insignificant (insignificant) damage; 3) a minor act should not be subjectively aimed at causing significant harm ${ }^{27}$. Taking into account the peculiarities of the

${ }^{24}$ Гладун О.З. Малозначність кримінальних і адміністративних правопорушень. Боротьба з організованою злочинністю і корупиією (теорія і практика). 2012. № 2. С. 103-112.

25 Дудоров О.О., Мовчан Р.О. Національне агентство 3 питань запобігання корупції на варті «попереднього» рубежу протидії корупції: основні проблеми та способи їх вирішення. Вісник ЛДУВС ім. Е.О. Дідоренка. 2018. Вип. 3 (83). С. 68.

${ }^{26}$ Проект Кодексу України про адміністративні проступки № 5558 від 26.05.2004. С. 14. URL: http://w1.c1.rada.gov.ua/pls/zweb2/webproc4_2?id=\&pf3516=5558\&skl=5 (дата звернення: 05.07.2020).

${ }^{27}$ Щодо встановлення малозначності діяння: Правова позиція Касаційного кримінального судуускладіВерховногоСудузгіднозПостановоювід04квітня 2019 рокуусправі№310/4064/17. URL: https://zakononline.com.ua/court-practice/show/2375? from $=\% \mathrm{D} 1 \% 81 \% \mathrm{D} 1 \% 82 . \% 2022 \% 20$

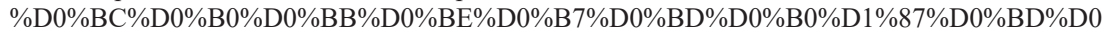
$\%$ BE $\%$ D $1 \% 81 \%$ D $1 \% 82 \%$ D $1 \% 96 \% 20 \%$ D0\%BF\%D1\%80\%D0\%B0\%D0\%B2\%D0\%BE\%D0\%B F $\%$ D0 $\%$ BE $\%$ D $1 \% 80 \% \mathrm{D} 1 \% 83 \% \mathrm{D} 1 \% 88 \% \mathrm{D} 0 \% \mathrm{~B} 5 \% \mathrm{D} 0 \% \mathrm{BD} \% \mathrm{D} 0 \% \mathrm{BD} \% \mathrm{D} 1 \% 8 \mathrm{~F}$ (дата звернення: 05.07.2020). 
analyzed administrative misconducts and specializing the noted legal position, we can distinguish the following two conditions for exemption (due to insignificance) from administrative liability for torts related to conflicts of interest:

1) The act must contain the full composition of one of the misconducts under Art. 172-7 of the Code on Administrative Offenses. If in a particular case there is no proper subject, subjective side, object or objective side of failure to notify of a real conflict of interest or action (decision-making) in the context of such a conflict of interest, the proceedings should be closed under p. 1 part 1 Art. 247 of the Code on Administrative Offenses («absence of an event and structure of an administrative offense»). Only after the identification of the entire composition of the illegal act, it is subject to analysis and evaluation for insignificance. In this regard, the conclusion seems obvious: the circumstances that indicate the absence of at least one element of the tort, can not justify the application of Art. 22 of the Code of Administrative Offenses, because their existence determines the termination of jurisdictional proceedings at an earlier stage. It should also be noted that administrative offenses related to a real conflict of interest can be committed only in the form of intent - this is the dominant (but not indisputable and not unalterable) approach to understanding the subjective side of the torts provided for in Art. 172-7 of the Code on Administrative Offenses. That is why the application of such criteria of insignificance of the studied deviations as: the subject «acted unintentionally», «careless form of guilt of the violator» seems polemical ${ }^{28}$. In such cases, the court should first explain why the proceedings are not closed due to the lack of corpus delicti (apparently due to the assumption / recognition of the variability of the subjective side of the latter); instead, decisions in which it is initially acknowledged that «the acts provided for in Art. 172-7 of the Code on Administrative Offenses, are acts with a formal composition, which can be committed only intentionally», and then exemption from liability is applied (Article 22), because the person acted «not intentionally» ${ }^{29}$.

2) The act does not constitute the social harm that is traditionally characteristic of the relevant offenses. It is important:

a) there is a comparison of a specific misconduct with the level of «normal» harmfulness of the conflict of interest. Therefore, we consider unfounded the use of the following criteria of insignificance for acts that contain the composition

${ }_{28}$ Постанова Віньковецького районного суду Хмельницької області від 23.05 .2019 р., справа № 680/222/19. URL: http://www.reyestr.court.gov.ua/Review/81923065 (дата звернення: 05.07.2020).

29 Постанова Рівненського міського суду Рівненської області від 04.03 .2020 р., справа № 569/1587/20. URL: http://www.reyestr.court.gov.ua/Review/88302407 (дата звернення: 05.07.2020). 
provided for in Art. 172-7 of the Code on Administrative Offenses - «there are no victims of the offense» ${ }^{30}$ (in the vast majority of such cases there are none), the committed «does not pose a great public danger ${ }^{31}$ (the latter is not typical of administrative misconducts), and so on. Similarly, the list of criteria of insignificance can be extended to the absurd, referring to the absence a priori of extraneous features: the act did not lead to death, to international conflict, to a nuclear explosion, to the threat to sovereignty, and the like;

b) insignificance is «own» quality of the offense (reflecting its relatively reduced harm at the time of commission) and does not apply to pre-tort characteristics of the subject or the specifics of post-tort behaviour of the latter (as a result of specialization of criminal law position of the Supreme Court $^{32}$ ). That is why the insignificance of the act should not be proved through: «sincere repentance» ${ }^{33}$; further good faith - after the official «learned of the conflict of interest, the conflict was resolved by him» ${ }^{34}$; traits of an entity that has not «previously been subject to disciplinary and administrative liability», has a «positive characterization» ${ }^{35}$, etc. For the purposes of criminal law qualification O.V. Us rightly emphasizes: «an act committed by a person can be qualified as insignificant, regardless of whether he has committed the relevant offense for the first time, or even repeatedly committed crimes. In this regard, it is impossible to recognize the correct practice of justifying the application of Part 2 of Art. 11 of the Criminal Code with references to the repentance of the subject of the crime, compensation for the damage caused by him and other circumstances that do not characterize the public danger of the act. The qualification of an act

${ }^{30}$ Постанова Гощанського районного суду Рівненської області від 12.05 .2020 р., справа № 557/510/20. URL: http://www.reyestr.court.gov.ua/Review/89190463 (дата звернення: 05.07.2020).

31 Постанова Полтавського апеляційного суду від 01.03.2019 р., справа № 532/2192/18. URL: http://www.reyestr.court.gov.ua/Review/80289636 (дата звернення: 05.07.2020).

32 Правовий висновок ВСУ щодо застосування судами ст. 11 КК України «про малозначність діяння, яке не є злочином» від 24.12.2015 р., справа № 5-221кс15. URL: https://protocol.ua/ua/ pravoviy_visnovok_vsu_shchodo_zastosuvannya_sudami_st_11_kk_ukraini_pro_maloznachnist_ diyannya_yake_ne_e_zlochinom/ (дата звернення: 05.07.2020).

33 Постанова Віньковецького районного суду Хмельницької області від 23.05.2019 р., справа № 680/222/19. URL: http://www.reyestr.court.gov.ua/Review/81923065 (дата звернення: 05.07.2020).

34 Постанова Синельниківського міськрайонного суду Дніпропетровської області від 17.06.2020 р., справа № 191/1408/20. URL: http://www.reyestr.court.gov.ua/Review/89858138 (дата звернення: 05.07.2020).

35 Постанова Володимир-Волинського міського суду Волинської області від 07.06.2019 р., справа № 154/1686/19. URL: http://www.reyestr.court.gov.ua/Review/82281922 (дата звернення: 05.07.2020). 
as insignificant is not affected by the fact that the person who committed it does not admit his guilt for its commission» ${ }^{36}$. This approach seems to be acceptable for administrative tort law; it provides a focus on establishing the degree of harmfulness of the misconduct-act (rather than concomitant factors) and opens a new space of «insignificance» (which is permissible in situations for which it was previously strongly denied - recidivism [Part 3 of Article 172-7 of the Code on Administrative Offenses], lack of repentance).

Since Art. $172-7$ of the Code on Administrative Offenses provides for misconducts with a formal composition, their insignificance can be conditioned / proved only by the type (nature) and intensity of the act (for example, taking procedurally erroneous measures to resolve conflicts of interest [but taking them] or failure to complete the necessary group of measures [although a significant part of them is done]).

\section{CONCLUSIONS}

One of the most controversial and problematic aspects of jurisdictional proceedings in administrative cases concerning conflicts of interest is the issue of admissibility, as well as contextual and applied motivation, exemption from liability due to the insignificance of the committed misconduct. Lawyers' views on the admissibility of the application of Art. 22 of the Code on Administrative Offenses to administrative misconducts related to corruption (including conflicts of interests) differ significantly. Categorically negative positions (within which experts give an unequivocally negative answer to this question - in the existing positive legal context and mainly for applied purposes) appear to the author as contrary to the positive requirements, contribute to the evasion of the leading entity from the implementation of law enforcement (evaluation) obligations, neglect the values of the rule of law and give political goals unreasonable priority over regulations. Within moderately negative visions, there is the possibility of applying Art. 22 of the Code on Administrative Offenses to administrative torts related to corruption, but this is regarded as due to the positive legal requirements of coercion, which in the future should be eliminated by appropriate legislation. Recognising the results of internal synchronous comparison, applied needs, the primacy of internal / qualitative incentives for the renewal of legal institutions, we consider the most justified moderately positive solution to the dilemma, according to which exemption (due to insignificance) in cases of administrative

${ }^{36}$ Ус О.В. Кваліфікація малозначного діяння. Держсава та регіони. Серія: Право. 2018. № 2(60). C. 61. 
misconducts connected with corruption is a perfectly acceptable (and in some cases even the only possible and legitimate) way to complete jurisdictional proceedings. Such dismissal does not destroy the public law mechanism for combating corruption and does not encourage new torts. On the contrary, if as a result of proceedings on a thematic misconduct Art. 22 of the Code of Administrative Offenses is applied, then: a) the principle of proportionality is affirmed and the «faith» of individuals in the justice of the law is strengthened (no less negative would be the situation when positivism and limited scope of «insignificance» would force sanctions for formal / insignificant deviations); b) the person (and others) is aware that even minor violations are not left without a balanced law enforcement assessment; c) for most officials, the «insignificance» of an administrative tort will result in exemption from specific, rather than any, liability (for state servants there is a very real prospect of disciplinary action for the relevant act and inclusion, on this basis, in USRPCO).

The problem of proper criteria for identifying the «insignificance» of administrative misconducts (and conflicts of interest, including) remains labidly developed, but their list clearly does not include: circumstances that indicate the absence of at least one element of the tort (they determine the termination of jurisdiction) at an earlier stage); the facts of absence a priori extraneous features (which are not characteristic of all specific offenses); pre-delict features of the subject of the misconduct and the specifics of his post-delict behaviour.

\section{SUMMARY}

The work is devoted to the study of the problems of acceptability and justification of exemption (due to insignificance) from administrative liability for misconducts related to conflicts of interest. It has been proved the inadmissibility of premature dogmatic-directive restriction of the jurisdiction of its functional legal obligations under Art. 22 on the Code on Administrative Offenses, when the subject of power actually refuses to legally assess the act as «insignificant». It has been established that the exemption from administrative liability for corruption-related misconduct does not destroy the public law mechanism for combating corruption and does not encourage new torts. It is criticized the application by the courts of such criteria of insignificance of administrative misconducts regarding conflict of interests as: lack of intent (negligent form of guilt), absence of victims of the offense, absence of its great public danger, sincere remorse of the person, further (post-tort) settlement of the conflict of interests and 
administrative responsibility, its positive characteristics, etc. The borrowing of criminal law has opened up a new space of «insignificance» (which turned out to be acceptable in relation to situations for which it was previously strongly denied - recidivism, lack of remorse, etc.).

\section{REFERENCES}

1. Кодекс України про адміністративні правопорушення : Закон України від 07.12.1984 № 8073-X. URL : https://zakon.rada.gov.ua/laws/ show/80731-10 (дата звернення: 05.07.2020).

2. Бурбан Л. У прокуратурі Львівщини скаржаться на недосконалість антикорупційного законодавства. Leopolis.news від 30 Січня 2017. URL : http://leopolis.news/u-prokuraturi-lvivskoyi-oblasti-zhaliyutsya-nanedoskonalist-antykoruptsijnogo-zakonodavstva/ (дата звернення: 05.07.2020).

3. Постанова Апеляційного суду Київської області від 19 грудня 2017 p., справа № 359/7200/17. URL : http://www.reyestr.court.gov.ua/ Review/71277204 (дата звернення: 05.07.2020).

4. Постанова Чугуївського міського суду Харківської області від 24 січня 2017 р., справа № 636/144/17. URL : http://www.reyestr.court.gov. ua/Review/64358464 (дата звернення: 05.07.2020).

5. Про засади державної антикорупційної політики в Україні (Антикорупційна стратегія) на 2014-2017 роки : Закон України від 14 жовтня 2014 року № 1699-VII. URL: https://zakon.rada.gov.ua/laws/ show/1699-18\#Tеxt (дата звернення: 05.07.2020).

6. Аналіз судової практики розгляду судами справ про адміністративні правопорушення, пов'язані з корупцією (ст.ст. 172-2 - 172-9 КУпАП) за 2016 р. Апеляційний суд Донецької області. 2017. URL : https://sl.dn.court. gov.ua/sud0544/pres-centr/general/364605/ (дата звернення: 05.07.2020).

7. Кримінальний кодекс України : Закон України від 05.04.2001 р. № 2341-III. URL : https://zakon.rada.gov.ua/laws/show/2341-14\#Tеxt (дата звернення: 05.07.2020).

8. Постанова Кролевецького районного суду Сумської області від 28 січня 2020 р., справа № 579/2252/19. URL: http://www.reyestr.court.gov.ua/ Review/87219703 (дата звернення: 05.07.2020).

9. Постанова Роменського міськрайонного суду Сумської області від 27 травня 2020 p., справа №585/692/20.URL:http://www.reyestr.court.gov.ua/ Review/89500524 (дата звернення: 05.07.2020).

10. Сенюк О. Протидія корупційним правопорушенням у Збройних Силах України та інших військових формуваннях. Протидія корупційним та іншим правопорушенням у військових формуваннях Украӥни: матеріали круглого столу (19 вересня 2017 року). Київ : Національна академія прокуратури України, 2017. С. 78-84. 
11. Іванов А. Розгляд у суді справ про адміністративні корупційні правопорушення. Місиеве самоврядування. 2015. № 5. URL : https://i.factor.ua/ukr/journals/ms/2015/april/issue-4/article-7116.html (дата звернення: 05.07.2020).

12. Хамходера О.П. Малозначність адміністративних проступків, що пов'язані з корупцією. Правові та інституційні механізми забезпечення розвитку України в умовах європейської інтеграцій: матеріали Міжнародної науково-практичної конференції (м. Одеса, 18 травня 2018 р.). У 2-х т. Т. 2 / від. ред. Г.О. Ульянова. Одеса : Гельветика, 2018. С. 48-52.

13. Хавронюк М., Химчук А. Моніторинговий звіт щодо ефективності реалізації Національним агентством 3 питань запобігання корупції у липні-грудні 2018 року повноважень щодо складання протоколів про адміністративні правопорушення, пов'язані 3 корупцією (станом на 1 січня 2019 року). Київ : ЦППР, 2019. 16 с.

14. Дудоров О.О. Узагальнення судової практики у справах про адміністративні правопорушення, пов'язані з корупцією. Київ, 2019. 253 c. URL : https://fileview.fwdedn.com/?url=https\%3A\%2F\%2Fmail.ukr. net $\% 2$ Fapi\%2Fpublic\%2Ffile_view\%2Flist $\% 3$ Ftoken\%3DWr3PDezpM3J Ww6jJAqHFFbiqP2FbV6nFh6ecAPp5ccEqnqc7ENtQF_JhCnsrCHGAlrA niwhVBddLw2aVZN49QNyVyeZ7gqftrrVgIw\%253A8dsXG9b0cuUfgWw R\%26r\%3D1579727886832\&default_mode=view\&lang=uk\#start=1 (дата звернення: 05.07.2020).

15. Гладун О.3. Малозначність кримінальних i адміністративних правопорушень. Боротьба з організованою злочинністю $i$ корупиією (теорія і практика). 2012. № 2. С. 103-112.

16. Діденко І.В. Адміністративна відповідальність за порушення вимог щодо запобігання та врегулювання конфлікту інтересів : дис. ... канд. юрид. наук. Київ, 2018. 232 с.

17. Дудоров О.О., Мовчан Р.О. Національне агентство 3 питань запобігання корупції на варті «попереднього» рубежу протидії корупції: основні проблеми та способи їх вирішення. Вісник ЛДУВС ім. Е.О. Дідоренка. 2018. Вип. 3(83). С. 60-73.

18. Соболь О. Проблемні питання апеляційного оскарження постанов у справах про адміністративні правопорушення, пов'язані з корупцією. Вісник прокуратури. 2017. № 11. С. 35-37.

19. Висновок Головного науково-експертного управління від 11.02.2020 р. на проект Закону України «Про внесення змін до деяких законодавчих актів України щодо посилення відповідальності за окремі правопорушення у сфері безпеки дорожнього руху». 10 c. URL : http://w1.c1.rada.gov.ua/pls/zweb2/webproc4_1?pf3511=67814 (дата звернення: 05.07.2020). 
20. Щодо порядку дій державних органів після визнання державних службовців судом винними у вчиненні корупційного правопорушення або правопорушення, пов'язаного $з$ корупцією : Роз'яснення НАЗК від 03.06.2020 p. №3. URL: https://nazk.gov.ua/wp-content/uploads/2020/06/3.pdf (дата звернення: 05.07.2020).

21. Положення про Єдиний державний реєстр осіб, які вчинили корупційні або пов'язані з корупцією правопорушення : затв. Рішенням НАЗК від 09.02.2018 р. № 166. URL : https://zakon.rada.gov.ua/laws/show/ z0345-18\#n13 (дата звернення: 05.07.2020).

22. Постанова Заводського районного суду м. Дніпродзержинська Дніпропетровської області від 08.07.2019 р., справа № 208/2949/19. URL : http://www.reyestr.court.gov.ua/Review/83035058 (дата звернення: 05.07.2020).

23. Постанові Київського апеляційного суду від 16.12.2019 р., справа № 365/572/19. URL : http://www.reyestr.court.gov.ua/Review/86394266 (дата звернення: 05.07.2020).

24. Аналіз судової практики розгляду справ про адміністративне правопорушення, розглянутих місцевими судами області та їх перегляд апеляційним судом Івано-Франківської області за I півріччя 2015 року. 2015. 32 c. URL : https://ifa.court.gov.ua/userfiles/file/ifa_sud/ANALIZ_ KYpAP.pdf (дата звернення: 05.07.2020).

25. Узагальнення застосування судами законодавства у справах про адміністративні правопорушення у сфері інтелектуальної власності (статті 51-2, 164-9 КпАП): Верховний Суд України від 01.01.2006 p. URL : http:// zakon3.rada.gov.ua/laws/show/na018700-06/print1516951598059782 (дата звернення: 05.07.2020).

26. Резнік С.О. Судова практика звільнення особи від адміністративної відповідальності у зв'язку зі малозначністю протиправного діяння. Право і суспільство. 2009. № 3. С. 69-73.

27. Про судову практику у справах про контрабанду : Постанова Пленуму Верховного Суду України від 03.06.2005 p. № 8. URL : http:// zakon5.rada.gov.ua/laws/show/v0008700-05 (дата звернення: 05.07.2020).

28. Проект Кодексу України про адміністративні проступки № 5558 від 26.05.2004. 287 c. URL : http://w1.c1.rada.gov.ua/pls/zweb2/webproc4_2?id= $\&$ pf3516=5558\&skl=5 (дата звернення: 05.07.2020).

$\begin{array}{ccccr}29 . & \text { Щодо } & \text { встановлення } & \text { малозначності } & \text { діяння: } \\ \text { Правова } & \text { позиція } & \text { Касаційного } & \text { кримінального } & \text { суду }\end{array}$ у складі Верховного Суду згідно з Постановою від 04 квітня 2019 року у справі № 310/4064/17. URL : https://zakononline.com.ua/ court-practice/show/2375? from=\%D1\%81\%D1\%82.\%2022\%20\%D0\% BC $\%$ D $0 \%$ B $0 \%$ D $0 \%$ B B $\%$ D $0 \%$ BE $\%$ D $0 \%$ B $7 \%$ D $0 \%$ BD $\%$ D $0 \%$ B $0 \%$ D1\%87\%D0\%BD\%D0\%BE\%D1\%81\%D1\%82\%D1\%96\%20\%D0\%BF\% 
D $1 \% 80 \%$ D0\%B0\%D0\%B2\%D0\%BE\%D0\%BF\%D0\%BE $\%$ D $1 \% 80 \%$ D 1 $\% 83 \% \mathrm{D} 1 \% 88 \% \mathrm{D} 0 \% \mathrm{~B} 5 \% \mathrm{D} 0 \% \mathrm{BD} \% \mathrm{D} 0 \% \mathrm{BD} \% \mathrm{D} 1 \% 8 \mathrm{~F} \quad$ (дата звернення: 05.07.2020).

30. Постанова Віньковецького районного суду Хмельницької області від 23.05.2019 p., справа № 680/222/19. URL : http://www.reyestr.court.gov.ua/ Review/81923065 (дата звернення: 05.07.2020).

31. Постанова Рівненського міського суду Рівненської області від 04.03.2020 p., справа № 569/1587/20. URL : http://www.reyestr.court.gov.ua/ Review/88302407 (дата звернення: 05.07.2020).

32. Постанова Гощанського районного суду Рівненської області від 12.05.2020 p., справа № 557/510/20. URL : http://www.reyestr.court.gov.ua/ Review/89190463 (дата звернення: 05.07.2020).

33. Постанова Полтавського апеляційного суду від 01.03.2019 р., справа №532/2192/18.URL: http://www.reyestr.court.gov.ua/Review/80289636 (дата звернення: 05.07.2020).

34. Правовий висновок ВСУ щодо застосування судами ст. 11 КК України «про малозначність діяння, яке не є злочином» від 24.12.2015 р., справа № 5-221кс15. URL : https://protocol.ua/ua/pravoviy_visnovok_vsu_ shchodo_zastosuvannya_sudami_st_11_kk_ukraini_pro_maloznachnist_ diyannya_yake_ne_e_zlochinom/ (дата звернення: 05.07.2020).

35. Постанова Синельниківського міськрайонного суду Дніпропетровської області від 17.06.2020 р., справа № 191/1408/20. URL : http://www.reyestr.court.gov.ua/Review/89858138 (дата звернення: 05.07.2020).

36. Постанова Володимир-Волинського міського суду Волинської області від 07.06.2019 р., справа № 154/1686/19. URL : http://www.reyestr.court.gov.ua/Review/82281922 (дата звернення: 05.07.2020).

37. Ус О.В. Кваліфікація малозначного діяння. Держава та регіони. Серія: Право. 2018. № 2(60). С. 58-63.

\section{Information about author: Khamkhodera O. P., $\mathrm{PhD}$ in Law,} Associate Professor at the Department of Administrative and Financial Law National University "Odesa Law Academy" 23, Fontanska doroha str., Odesa, 65009, Ukraine 